Meta

Journal des traducteurs

Translators' Journal

\title{
Mediated and Marginalised: Translations of Modern and Contemporary Chinese Literature in Spain (1949-2010)
}

\section{Maialen Marin-Lacarta}

Volume 63, numéro 2, août 2018

URI : https://id.erudit.org/iderudit/1055141ar

DOI : https://doi.org/10.7202/1055141ar

Aller au sommaire du numéro

Éditeur(s)

Les Presses de l’Université de Montréal

ISSN

0026-0452 (imprimé)

1492-1421 (numérique)

Découvrir la revue

Citer cet article

Marin-Lacarta, M. (2018). Mediated and Marginalised: Translations of Modern and Contemporary Chinese Literature in Spain (1949-2010). Meta, 63(2),

306-321. https://doi.org/10.7202/1055141ar
Résumé de l'article

Cet article s'articule autour de l'histoire et de la réception des traductions de littérature chinoise moderne et contemporaine en Espagne.

Quatre-vingt-quatre traductions de littérature chinoise moderne et contemporaine ont été publiées en Espagne, en espagnol et en catalan, entre 1949 et 2010. En partant de ce corpus peu étudié, deux arguments reliés entre eux sont avancés dans cet article : la marginalisation de la littérature chinoise moderne et contemporaine en Espagne et la médiation des systèmes littéraires anglophone et francophone dans la réception espagnole de cette littérature.

Pour tester ces arguments, l'étude retrace l'histoire des traductions, se concentre sur l'évolution du type de traduction (directe et indirecte) et fournit des exemples de paratextes (quatrièmes de couverture et préfaces) et critiques de traductions. Après une analyse de la prédominance de traductions indirectes, trois thèmes récurrents déduits de l'analyse des paratextes et critiques sont présentés : (a) la préférence pour la valeur documentaire, (b) l'insistance sur la différence et (c) l'accent sur le politique et le trauma (la censure, la dissidence et la révolution culturelle). En outre, les liens entre ces thèmes récurrents dans la réception espagnole de la littérature chinoise et l'orientalisme européen et les area studies sont démontrés. Finalement, l'histoire récente des traductions de la littérature chinoise moderne et contemporaine en Espagne nous aide à réfléchir sur la complexité et la nature hiérarchique des échanges littéraires à échelle mondiale.
Ce document est protégé par la loi sur le droit d'auteur. L'utilisation des services d'Érudit (y compris la reproduction) est assujettie à sa politique d'utilisation que vous pouvez consulter en ligne.

https://apropos.erudit.org/fr/usagers/politique-dutilisation/ 


\title{
Mediated and Marginalised: Translations of Modern and Contemporary Chinese Literature in Spain (1949-2010)
}

\author{
MAIALEN MARIN-LACARTA \\ Hong Kong Baptist University, Hong Kong SAR \\ mmaialen@hkbu.edu.hk
}

\section{RÉSUMÉ}

Cet article s'articule autour de l'histoire et de la réception des traductions de littérature chinoise moderne et contemporaine en Espagne. Quatre-vingt-quatre traductions de littérature chinoise moderne et contemporaine ont été publiées en Espagne, en espagnol et en catalan, entre 1949 et 2010. En partant de ce corpus peu étudié, deux arguments reliés entre eux sont avancés dans cet article: la marginalisation de la littérature chinoise moderne et contemporaine en Espagne et la médiation des systèmes littéraires anglophone et francophone dans la réception espagnole de cette littérature. Pour tester ces arguments, l'étude retrace l'histoire des traductions, se concentre sur l'évolution du type de traduction (directe et indirecte) et fournit des exemples de paratextes (quatrièmes de couverture et préfaces) et critiques de traductions. Après une analyse de la prédominance de traductions indirectes, trois thèmes récurrents déduits de l'analyse des paratextes et critiques sont présentés: (a) la préférence pour la valeur documentaire, (b) l'insistance sur la différence et (c) l'accent sur le politique et le trauma (la censure, la dissidence et la révolution culturelle). En outre, les liens entre ces thèmes récurrents dans la réception espagnole de la littérature chinoise et l'orientalisme européen et les area studies sont démontrés. Finalement, l'histoire récente des traductions de la littérature chinoise moderne et contemporaine en Espagne nous aide à réfléchir sur la complexité et la nature hiérarchique des échanges littéraires à échelle mondiale.

\footnotetext{
ABSTRACT

The history and reception of translations of modern and contemporary Chinese literature in Spain form the basis of the discussion in this article. Eighty-four translations of modern and contemporary Chinese literature were published in Spain - either in Spanish or in Catalan - between 1949 and 2010. Using this under-researched corpus as a startingpoint, this article explores two interrelated premises: the marginalisation of modern and contemporary Chinese literature in Spain and the mediation of its Spanish reception by Anglophone and Francophone literary systems. To do so, the study investigates the history of translations, pays attention to the evolution of types of translation (direct and indirect), and uses concrete examples from paratexts (back covers and prefaces) and translation reviews. After a discussion of the predominance of indirect translations, three recurring motifs inferred from an analysis of the paratexts and reviews are presented: (a) a preference for documentary value, (b) an insistence on difference and (c) an emphasis on politics and trauma (censorship, dissidence and the Cultural Revolution). In addition, I demonstrate the connections between these recurring motifs in the Spanish reception of Chinese literature in relation to European orientalism and area studies. Ultimately, the recent history of translations of modern and contemporary Chinese literature in Spain helps us to reflect on the complexity and hierarchical nature of literary exchanges on a global scale.
} 


\section{RESUMEN}

Este artículo trata de la historia y la recepción de las traducciones de literatura china moderna y contemporánea en España. Entre 1949 y 2010, se publicaron 84 traducciones de literatura china moderna y contemporánea en España, en castellano y en catalán. Partiendo de este corpus que ha sido poco estudiado, el artículo propone dos argumentos interrelacionados: la marginalización de la literatura china moderna y contemporánea en España y la mediación de los sistemas literarios anglófono y francófono en la recepción española de esta literatura. Para ello, el estudio se centra en la historia de las traducciones, presta atención a la evolución de los tipos de traducción (directa e indirecta) y ofrece ejemplos concretos de paratextos (cubiertas posteriores y prefacios) y críticas de traducciones. Después de demostrar la predominancia de las traducciones indirectas, presentamos tres reclamos recurrentes que deducimos del análisis de los paratextos y las críticas: (a) la preferencia por el valor documental, (b) la insistencia en la diferencia y (c) el enfásis en política y trauma (censura, disidencia y la Revolución cultural). Además, demostramos las conexiones entre estos reclamos recurrentes en la recepción española de la literatura china en relación con el orientalismo europeo y los estudios de area. Por último, la historia reciente de las traducciones de literatura china moderna y contemporánea en España nos ayuda a reflexionar sobre la complejidad y la naturaleza jerárquica de los intercambios literarios a escala global.

\section{MOTS-CLÉS/KEYWORDS/PALABRAS CLAVE}

histoire de la traduction, traduction indirecte, réception littéraire, littérature chinoise moderne et contemporaine en espagnol, paratexte

translation history, indirect translation, literary reception, modern and contemporary Chinese literature in Spanish, paratext

historia de la traducción, traducción indirecta, recepción literaria, literatura china moderna y concetemporánea en español, paratexto

\section{Introduction}

In a conference on the contemporary Chinese writer Jia Pingwa (贾平凹) ${ }^{1}$ held in Hong Kong in 2015, the scholar and translator Carlos Rojas remarked that some American publishers commission translations of Chinese literature only after the French translations have been issued. Similarly, I pointed out that Spanish publishers often decide to commission the translation of a Chinese novel only after the English or French version has been published. I suggest that, as a consequence, there is a certain homogenisation in the reception of modern and contemporary Chinese literature in French, English and Spanish, because the same authors and literary works are very often circulated in these languages. In support of this hypothesis, this article explores two interrelated premises: the marginalisation of modern and contemporary Chinese literature in Spain and the mediating role of English and French translations in the Spanish reception of this literature.

Scant attention has been paid to the history and reception of translations of Chinese literature in Spain. Arbillaga (2003) compiled a catalogue of texts about China published in Spain, classifying all such texts as Chinese literature: books originally written in different languages, direct and indirect translations, novels about China, scientific and informative books and even books about personal development. Arbillaga's (2003) book is less an analytical study than a catalogue without clear delimitations. In addition, a few scholars have published articles on translations into Catalan, such as Prado-Fonts (2001) and Ollé (2007), or into Basque, such as 
Jaka Irizar and Marin-Lacarta (2014). Marin-Lacarta (2012; 2014) presented a general overview of translations of modern and contemporary Chinese literature in Spain with a focus on paratexts, complementing the analysis presented in this article. Here, I test a solid hypothesis and two interrelated premises regarding the reception of modern and contemporary Chinese literature in Spain before 2010.

To verify this hypothesis, the article discusses various symptoms of the marginalisation and mediation of modern and contemporary Chinese literature in the process of its reception in Spain. A range of sources and methods are used to illustrate these symptoms. After introducing the key concepts used in the article, I present an account of the types of translation published (direct and indirect) and demonstrate the predominance of mediated translations. I then show that the recurring motifs that appear in prefaces, on back covers and in reviews relegate $20^{\text {th }}$-century Chinese literature to a marginal position. The types of texts translated (i.e. the most frequently translated genres and themes) are also explored to support my main argument.

The concepts of mediation and marginalisation, which I use as part of the main argument of this article, deserve special attention. By mediation, I refer to the influence of Anglophone and Francophone literary systems on the translation and reception of modern and contemporary Chinese literature in Spain. The article provides evidence of this mediation, most obviously in the number of indirect translations published, but also in the choice of works for translation (both direct and indirect) and the ways in which they have been presented to readers. The concept of mediation is therefore closely related to the notion of indirectness. Marin-Lacarta (2017) suggested that indirectness involves both human and textual mediation, and that textual mediation is the less studied of the two. However, textual mediation has recently received more attention from translation scholars for its complex reflection of power relations, rendering visible the hierarchies of literature and highlighting the intricacies of the process of literary translation (Assis Rosa, Pięta and Bueno Maia 2017). In this study, the influence of various agents in the process of translation, along with paratexts and translations in English and French, are shown to affect the production and reception of Spanish translations of modern and contemporary Chinese literature, demonstrating the intertwining relationship of textual and human mediation.

I do not seek to imply that the marginal position of modern and contemporary Chinese literature in Spain is inevitable or that marginality is intrinsic to this type of literature. On the contrary, I suggest that this marginal positioning is a consequence of processes of selection, translation and literary reception. In other words, modern and contemporary Chinese literary works do not have less literary value than other literatures per se, but they are usually presented to readers in such a way that their aesthetic value is denied, and their meaning is over-politicised.

Some scholars have argued that the marginal status of certain literatures is connected with the nature of the literary production, that is, with how that literature is written. For instance, Jameson (1986) argued in a controversial article that all "Third World literatures" are necessarily national allegories with socio-political and nationalist content and are thus reflections of society. Jameson's article was criticised by numerous scholars, notably Ahmad (1992), who objected to the essentialism of Jameson's argument and the binary opposition between Western and non-Western cultural production on which it was predicated. Another interesting objection was 
made by Shih (2004), who claimed that any text can be interpreted as an allegory if the reader chooses to do so. She attributed to the reader or critic the sole responsibility for creating meaning from the texts and suggested that Jameson applied just one hermeneutical code in his readings of literature of the developing world. In this article, I show that the processes of selection, translation and reception tend to create meaning to the detriment of alternative interpretations. As a consequence, the ways in which modern and contemporary Chinese literature is received and interpreted in Spain contribute to its marginalisation.

This article can be considered to contribute to the study of literary transfer between semi-peripheral and peripheral languages. Research in the field of translation studies has focused on central languages; exchanges between languages in the margins of the global literary system have received less attention (Cronin 2009; Pieta 2016). According to Heilbron and Sapiro (2007: 95-96), Spanish is a semi-peripheral language because texts translated from Spanish represent between $1 \%$ and $3 \%$ of the world market of translated literature, and Chinese is a peripheral language because translations from Chinese have a share of less than $1 \%$ in this market. In terms of number of speakers or volume of literary production, Spanish and Chinese are central or dominant languages, especially in comparison with the minority languages used in Spain and China, but from the perspective of translated literature they can be considered semi-peripheral. The study of literary transfer between semi-peripheral languages has much to offer the field of translation studies: it can contribute to the discipline by questioning theorisations based only on central languages (Cronin 2009) and by exposing complex power relations and their consequences.

The research for this article focused on book translations published in Spain in any of the country's official languages (Spanish, Catalan, Galician and Basque). Before 2010, however, most modern and contemporary Chinese literature was translated only into Spanish or Catalan. ${ }^{2}$ The data show that 84 translations of modern and contemporary Chinese literature were published between 1949, when the first translation of a modern Chinese literary text was issued, and 2010. This article does not include translations published in Spanish in China or Latin America because of a lack of relevant corpus. Future publications could study translations published in China to help us understand the types of texts that Chinese publishers are exporting and the ways in which they are presented to readers. Foreign Languages Press (Waiwen chubanshe 外文出版社) published Spanish translations of Chinese literature until the 1990s; and more recently, China Intercontinental Press (Wuzhou chuanbo chubanshe 五洲传播出版社) published a series of translations of contemporary Chinese literature in Spanish. In Latin America, very few translations have been published, of which most have been issued by El Colegio de México. It should also be noted that in this article the term "modern and contemporary Chinese literature" refers to literature published after 1917, which is traditionally considered the beginning of modern literature, as designated by Hu Shi (胡适) and Chen Duxiu (陈独秀) in the literary magazine Xin qingnian (新青年). The publication of Lu Xun's (鲁迅) A Madman's Diary (Kuangren riji 狂人日记) in 1918 is also considered a key event in this timeline. However, it should be noted that various academics have questioned the definition of literary modernity in China and dated the inception of modern Chinese literature to the end of the Qing dynasty (Dolezelova-Velingerova 1977; Lee 1989; Wang 1997). 


\section{2. (In)directness of translations: a brief history}

Most of the translations of modern and contemporary Chinese literature published in Spain before 2010 were indirect translations. As shown in Figure 1, 35 direct translations and 49 indirect translations were published between 1949 (when the first translation of a modern Chinese literary text was issued) and 2010. Of the 49 indirect translations, 27 were made from English and 14 from French. I also found two indirect translations with unknown mediating languages, but biographical information about the translators indicates that they translated either from English or from French. In addition, an anthology translated from both English and French and five translations from other languages (two from Italian, two from Portuguese and one from Spanish into Catalan) were published between 1949 and 2010. Of the 84 translations issued in this period, 12 were in Catalan (six directly translated and six indirectly translated).

\section{FIGURE 1}

(In)directness in translations of modern and contemporary Chinese literature in Spain (1949-2010)

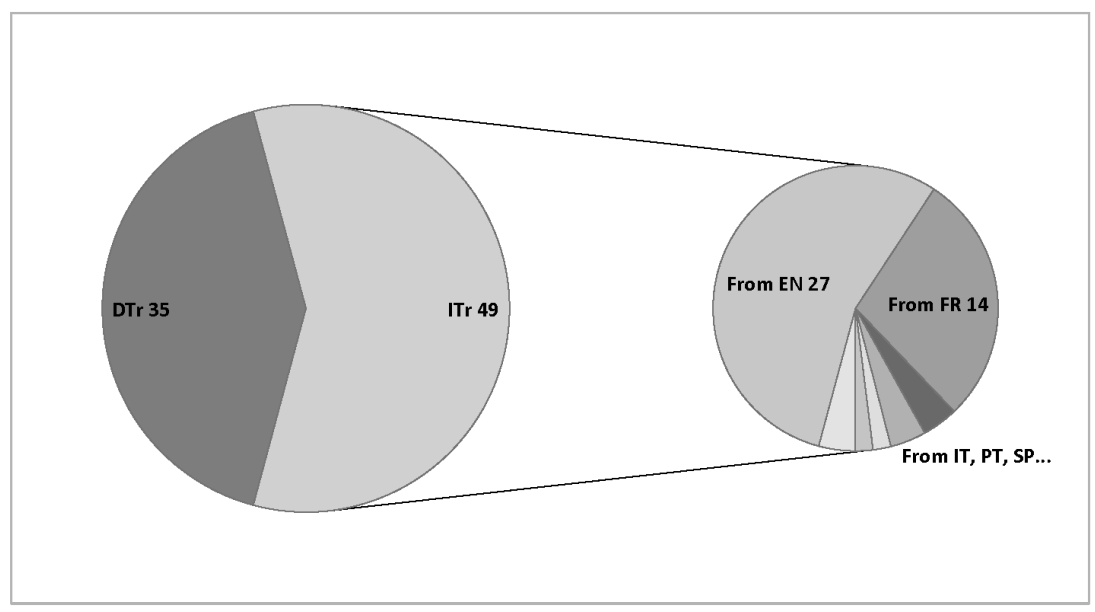

Although Figure 1 indicates the predominance of indirect translation, it provides no information on the historical evolution of direct and indirect translation. Toury (1995: 133) and Xu (2003: 199) suggested that the recourse to indirect translation would gradually diminish with the development of cultural exchange and translators' growing sense of obligation to recreate the features of source texts. However, the data I have gathered contradict these hypotheses, showing that although the number of direct translations increased in the 1980s, the number of indirect translations grew threefold between 2001 and 2010 .

The reception of translations of modern and contemporary Chinese literature in Spain can be divided into three chronological stages, based on key events: from 1949 to 1977, from 1978 to 2000 and from 2001 to 2010, as shown in Figure 2. In the first stage, only a few translations of Chinese literature were published in Spain, most of which were indirect. The majority were translations of Mao Zedong's (毛泽东) poetry, 
due to heightened interest in Maoism in Spain after Franco's rule, and indirect translations of Lu Xun's short stories. The two direct translations published in this period were anthologies of poetry - both classical and modern, but primarily classical translated by Marcela de Juan, one of the few translators of Chinese at the time.

FIGURE 2

Translations of modern and contemporary Chinese literature in Spain (1949-2010)

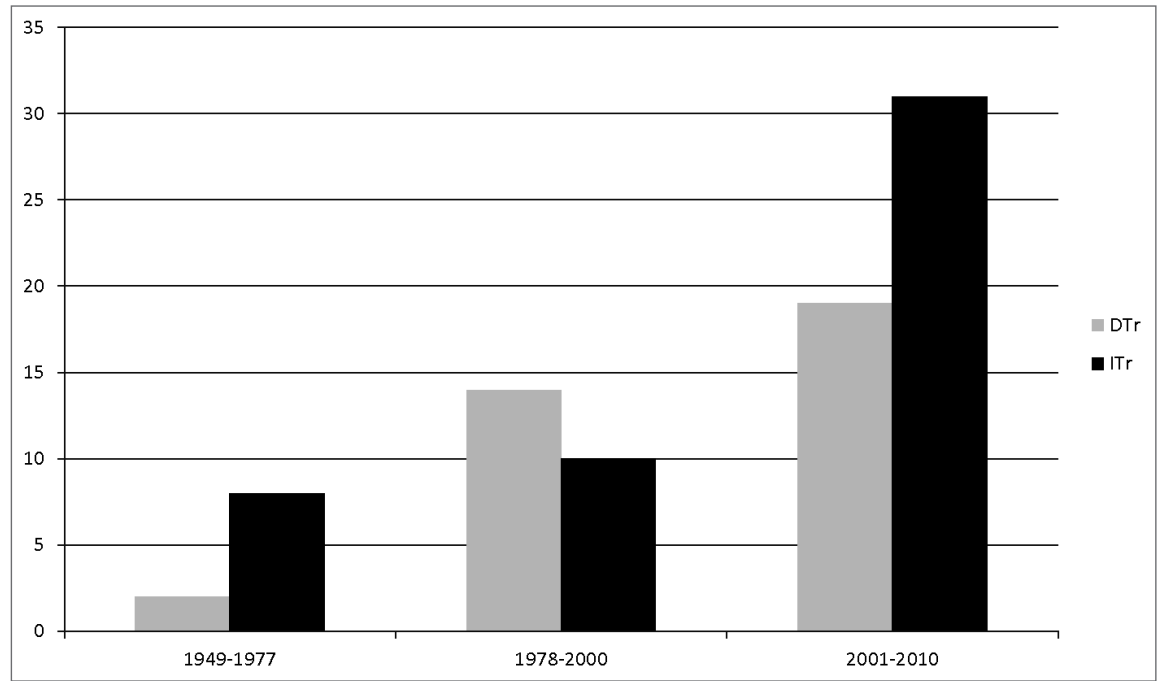

1978 is not a randomly chosen date, as this year saw the publication of the first direct translation of Lu Xun's short-story collection Nahan (呐喊), by Iñaki Preciado. That same year, the University of Granada launched a programme in Chinese translation, and diplomatic relations between China and Spain were re-established after decades of silence. Between 1978 and 2000, the number of translations of contemporary and modern Chinese literature published in Spain increased considerably, along with the variety of authors translated and the translators who carried out the translations. As shown in Figure 2, 14 direct translations and 10 indirect translations of contemporary and modern Chinese literature were published between 1978 and 2000.

2000 can be considered a key date because Gao Xingjian (高行健) was awarded the Nobel Prize in this year, which increased the number of translations not only of his works - Gao Xingjian and the 2012 Nobel Prize winner Mo Yan are the most frequently translated Chinese authors - but of modern and contemporary Chinese literary works more broadly. Fifty modern and contemporary Chinese literary works were translated in the 9 years between 2001 and 2010, compared with only 24 such translations in the 22 years between 1978 and 2000.

The most frequently translated genre between 2001 and 2010 was fiction, especially in novel form. Only eight novels were directly translated, with another 25 translated predominantly from English and French (only one novel was translated from Italian). Clearly, therefore, the 1980s saw a decline in indirect translation as the number of Chinese translators grew, but later, after 2000, indirect translation became much more prominent. However, I also discovered from interviews with translators 
and publishers that most of the Chinese novels translated between 2001 and 2010 both directly and indirectly - were chosen by the publishers after having read (or heard about) the English or French translations; in most cases, the publishers encountered these novels at international book fairs or through literary agents and English and French publishers. Therefore, even direct translations were mediated by English and French translations.

This suggests that the factors promoting indirect translation go beyond constraints such as a lack of translators and linguistic distance. The evolution of indirect translation, as evident from the data reported above, was more complex: influenced by the development of a globalised literary system in which the circulation of literature depended on differences in power between systems. The increasing lack of tolerance for indirect translation predicted by Toury (1995) was reflected not in a decline in indirect translation but in a growth of hidden indirect translations. In a hidden indirect translation, the "information included on the credit page leads readers to believe the book has been translated directly" (Marin-Lacarta 2012). In many such translations, only the original Chinese title and the Spanish translator were mentioned, omitting the mediating text and translator.

\section{Recurring motifs in paratexts and book reviews}

As Genette (1987: 7-8) argued, paratextual elements constitute a threshold, a vestibule, that readers may decide to cross on encountering a text. They offer a space of both transition and transaction, because there is an action, a strategy, and an influence on the reader. In addition, paratexts create concrete meaning, fostering a particular interpretation of the text. Therein lies the importance of paratextual elements to researchers investigating the discourse or image of a foreign literature. Similarly, book reviews and journalistic articles offer valuable insights into the criteria used by critics to assess a literary work. ${ }^{3}$

This section presents the conclusions drawn from analysis of the paratexts of translations and reviews. I discuss recurring motifs that appear in editorial peritexts, specifically back covers and prefaces, and show how these motifs have contributed to the marginalisation of modern and contemporary Chinese literature in Spain, the second key premise of my argument.

These recurring motifs are connected with the legacy of European orientalism as well as other problems associated with area studies, which are intimately linked to the "hegemonic ordering of the post-World War II world by the United States" (Dirlik 2010: 7-8). French, British and American approaches to studying China and Chinese literature have influenced the Spanish reception.

Although the study of Chinese literature in France shows no clear strategic orientation in the $21^{\text {st }}$ century, from the $16^{\text {th }}$ to the $19^{\text {th }}$ century, China was seen by French scholars as ahistorical, immutable and reified, as described by Bergère (1995: 13). In addition, Détrie and Moura (2001) identified a strong emphasis on difference between the Western world and the Orient in the French study of China between the $17^{\text {th }}$ and $19^{\text {th }}$ centuries. These perceptions are consistent with the arguments made by Said (1978) in Orientalism.

In the context of the United States, Miyoshi and Harootunian (2002: 12) argued that the Cold War discourse was a continuation of imperialism, and that this discourse 
persists in the guises of neoliberalism and globalisation. They also suggested that the discipline of area studies insists on difference. The close links between area studies and politics, economy and the European orientalist legacy have had consequences for the study of Asian literatures. Chow (1993: 127) argued that these consequences persist as a form of contemporary orientalism and claimed that "[o]f course, modern Asia, too, is amply investigated. It simply does not produce 'literature." She further argued that the socio-historical content of Chinese literary works continues to be emphasised in Anglophone academia, which means that literature's ability to subvert informationalization is neglected. I would suggest that literature's capacity to question and play with history, fable and fictionality is also ignored. In sum, the perceived otherness, difference and distance of Chinese culture lead to a focus on the documentary value and difference of Chinese literature. The Spanish semi-peripheral reception has therefore been strongly influenced by the central reception of Chinese literature and the features mentioned in the following section are not unique to the Spanish context; they can also be found in the Anglophone and Francophone readings of modern and contemporary Chinese literature.

\subsection{Preference for documentary value}

The following selection of quotations from the back covers of both direct and indirect translations of modern and contemporary Chinese literature published in Spain in the 1990s and 2000s reveals an emphasis on the documentary value of these literary works.

This work brings us closer to Chinese society today, which resembles and differs from ours in many respects. (Tie Ning 铁凝 1983/1989) ${ }^{4}$

Forty years of the recent history of China in a novel that should be read with a napkin around the neck. (Lu Wenfu 陆文夫1983/1994) ${ }^{5}$

It has the added value of focusing on a real character with epic overtones. (Lilian Lee 李碧华 1990/1995) ${ }^{6}$

[It is a] chronicle of three women in present-day China. Chinese society, like many other societies worldwide, continues to be driven by the logic of men. (Zhang Jie 张洁 $1982 / 1995)^{7}$

[It is] a profound and moving picture of life in China. (Wang Anyi 王安忆1985/1996) ${ }^{8}$

[It is] an impressive personal and sociological testimony of a Chinese student who experienced first-hand the terrible repression of the summer of 1989. (Hong Ying 虹 影 $1992 / 1998)^{9}$

With a raw intensity, frankness and lack of inhibition, Daughter of the River traces the trajectory of China through the life of a woman. (Hong Ying 1997/2005) ${ }^{10}$

An Oriental tragedy that takes us to a remote and contemporary China that remains largely unknown today. (Mo Yan 莫言 1988/2008) $)^{11}$

In all of these examples, the information included on the back covers of the novels stresses their documentary, testimonial and realist value; language and style are often omitted. I chose examples from the back covers of novels that were first published in China during the 1980s and 1990s and thus do not belong to the restricted socialist canon of the previous decades. The above excerpts insist on a concrete meaning and concrete values of the texts. Like documentary films or reportage, the novels 
are valued for offering a social picture of China, showing the reader what Chinese society, history and culture are like and reflecting the transformation of China.

As a result, literary texture is neglected. This tendency was criticised by Braester in relation to the reception of Chinese literature in English, as follows.

The study of non-Western literature and film has largely tended toward an "area studies" approach, privileging paradigms taken from the social sciences. In focusing on production data, readers' reception of works, and literature as a reflection of national and transnational sociopolitical and economic trends, scholars have often neglected the inner resistance and conflicting messages within specific texts. Literature differs from other forms of discourse in its emphasis on the texture of the text. How things are said is just as important as what is said - if not more important. (Braester 2003: xi, my emphasis)

The importance of literary texture needs to be reiterated in the context of the reception of modern and contemporary Chinese literature. As evident from the several paratextual excerpts above, literary texture is often overlooked in favour of documentary value. It is vital to be aware of the danger of regarding a novel simply as a realist picture of China in a certain period, without considering the fictional elements that are, after all, the essence of any novel. As Prado-Fonts (2008) observed, these fictional elements are obvious to readers of other historical novels, such as The Name of the Rose (Eco 1980/1983), but a reminder seems necessary for readers of $20^{\text {th }}$-century Chinese literature in Spain.

A preference for the documentary value of modern and contemporary Chinese literature as received in Spain is also clear from the types of texts translated in the period under study. Most of the translations published before 2000 could be seen to have documentary value, such as realist works, literary reportage, historical novels and semi-autobiographical novels. Hardly any translations were made of modernist and experimentalist literature from the 1930s or the 1980s, with the exception of two works from the 1980s: Bodong (波动) by Bei Dao (北岛), translated by Dolors Folch, and Liangchu ni de shetai huo kongkong dangdang (亮出你的舌苔或空空荡荡) by Ma Jian (马建), translated by Sara Rovira. Translations of $20^{\text {th }}$-century poetry were also very scarce. Poetry is the genre in which literary texture is most important, and the genre most distant from documentary texts. A few translations were made of poetry by Javier Martin Ríos, such as anthologies by Dai Wangshu (戴望舒) and Wen Yiduo (闻一多). In addition, Lu Xun's Yecao (野草) was translated into Catalan by Sean Golden. However, only one translation of poetry was originally published in Chinese after the 1980s: Bei Dao's Lingdu yishang de fengjing (零度以上的风景), translated by Luisa Chang. We can thus conclude that translations of modern and contemporary Chinese poetry are in a marginalised position in comparison with translations of classical Chinese poetry and modern fiction. Moreover, most of the translations published before 2000 were translations of fiction that reflected Chinese social reality.

At this point, it is necessary to reflect at least briefly on the history of $20^{\text {th }}$-century Chinese literature. It would be inaccurate to argue that the preference for fiction reflecting the social reality of China is exclusive to the reception of this literature in Spain. We should not forget that Maoism brought a restricted vision of literature, and that Chinese literature was almost exclusively limited to socialist realism and related political content from the 1940s until the late 1970s. This affected not only 
literary production but the appreciation of Chinese writers from the 1920s and 1930s, who were either erased from literary history, such as Shen Congwen (沈从文), or canonised as political militants, such as Lu Xun. However, from the 1980s onwards, both literary studies and literary production in China opened up: previously ignored authors were rediscovered and new literary movements appeared.

Therefore, considering the evolution of Chinese literature from the 1980s and the heightened interest in this literature after the Nobel Prize was awarded to Gao Xingjian, one might expect the orientation of translation after 2000 to have shifted away from texts of documentary value. Certainly, it should be noted that since 2000, translations have been made of contemporary authors whose styles are varied and who use modernist and postmodernist techniques, such as Wang Shuo (王朔), Xu Xing (徐星), Bi Feiyu (毕飞宇), Han Shaogong (韩少功), Yan Lianke (阎连科), Su Tong (苏童), Yu Hua (余华) and Mo Yan. However, the ways in which $20^{\text {th }}$-century Chinese novels help us to understand Chinese history, politics and society continue to be emphasised, and literariness continues to be side-lined. This is why I began this section with quotations from the back covers of novels written after the 1980s and translated in the 1990s and 2000s. The text on their back covers stresses the novels' documentary, realist and testimonial value, rarely referring to genre, language or style.

\subsection{Insistence on difference}

A second recurring motif in the paratexts of translations of modern and contemporary Chinese literature in Spain is an insistence on difference. This motif is connected to orientalist ideas of the radical difference between Chinese culture and the experiences of a Spanish readership. Some of these myths suggest that Chinese culture has remained unchanged for thousands of years, and that the Chinese language is indecipherable, as the examples below demonstrate.

The following quotation is taken from the preface to a translation of Mao Zedong's poetry published in 1975, which highlights the mysteriousness and indecipherability of the Chinese language.

I would say that in Chinese there are no words, but merely sounds that represent concrete reality. (Seabra 1975: 19) $)^{12}$

The next example is taken from the back cover of a translation of Lu Xun's Nahan.

What attracts the reader more powerfully across Lu Hsun's production is his ability to synthesise and recreate an exotic and distant world while at the same time bringing it closer to the reader from within, stripping it of all local colour and reducing it to its essence, to its skeleton, to transmit a universally comprehensible human foundation. (Lu Xun 1923/1971) $)^{13}$

In this example, the text on the back cover suggests that although China is a distant and exotic place, it possesses a shared human essence that the author has been able to identify and transmit.

A similar insistence on difference, exoticism and mysticism is evident in many book reviews of modern and contemporary Chinese literature. Below are two examples. 
Behind contemporary [Chinese] literature there is much more, because China has always attracted interest as an exotic and legendary country. (Soler-Pont 2008) ${ }^{14}$

This was published in a newspaper article that reviewed several translations of contemporary Chinese and Sinophone literature, as well as translations of works originally written in English or French by ethnic Chinese living in France, Britain and the United States. The title of the article was "An immense and unknown literature: an introduction to a literature of millenary roots." This title also refers to the ahistorical and immutable qualities of Chinese literature.

The second example is taken from a review of a translation of Meishijia by Lu Wenfu.

[...] the recent presence of a generation of very young writers determined to overcome historical trauma and transmit in their works the dramatic changes that are nowadays taking place in the ancestral and impenetrable Chinese society. [...] China and its traditions come from long ago and its millenary history trivialises what was intended as an irreversible revolution. (Lafuente 1994) ${ }^{15}$

These examples are representative of a tendency in the reception of modern and contemporary Chinese literature in Spain to insist on difference by transmitting simplistic and exotic ideas about China. There is also a tendency to oppose the East and the West, or the Orient and the West, as if it were possible to position two cultures at opposite poles. This recurring motif, again, is a symptom of the biased assessment of this literature in its Spanish reception.

\subsection{Politics and trauma: censorship, dissidence and the Cultural Revolution}

Other key ideas repeated in paratexts and book reviews of Spanish translations of modern and contemporary Chinese literature are related to censorship, dissidence and the Cultural Revolution.

The following quotations from the back covers of novels show how references to censorship are used to attract readers.

Since the publication of this novel she has been forbidden to return to China.' (Hong Ying 1992/1998) ${ }^{16}$

[The novel has been] banned because it is "decadent, vicious and a slave to foreign culture." [...] From the moment that Chinese authorities banned the novel and publicly burned 40,000 copies, it received international attention. (Weihui 周卫慧 1999/2002) ${ }^{17}$

La nina de Pequin is a transgressive novel that has been banned in China. [...] As a result of her boldness, Chun Sue is now forbidden to leave China. (Chun Sue 春树 $2002 / 2003)^{18}$

The best contemporary Chinese author, exiled from his country. (Yan Lianke $2005 / 2008)^{19}$

The theme of censorship is even more prominent in book reviews, in which Wang Shuo, Yu Hua, Mo Yan, Gao Xingjian and most diasporic authors are described as banned or censored authors. ${ }^{20}$ When censorship is mentioned in back covers and book reviews, a complex phenomenon is simplified and used for advertising purposes. For example, authors with censored novels are described as "banned authors." The case of Mo Yan's novel Fengru feitun (丰乳肥臀), described as “banned” and “censored” 
in Spanish book reviews, is a good example. After receiving a prize from the literary magazine Dajia in 1997, the novel became controversial and its publication was halted. However, the novel was reissued several years later. This demonstrates the dynamic and complex nature of censorship in China, where a novel can first receive a prize and then undergo censorship before its author is once again considered a nationally recognised and award-winning writer. The authors of paratexts and book reviews also claim that some authors are forbidden from returning to China, such as Hong Ying; according to Hong's blog, however, she lives between Italy, London and Beijing. ${ }^{21}$ The intricate phenomenon of Chinese censorship has been extensively oversimplified in the Spanish reception of modern and contemporary Chinese literature.

Another motif frequently found in paratexts and book reviews is the description of diasporic authors as "exiled" or "dissident." Gao Xingjian's case is a pertinent example. Lovell (2006) showed that the Swedish Academy praised the universal value of his writing in a press release but referred only to his autobiographic novels (Lingshan 灵山 and Yige ren de shenjing一个人的圣经) and his most political play (Taowang 逃 亡). Gao Xingjian's avant-garde and postmodernist plays occupied only a quarter of the press release, leading Lovell (2006: 167) to draw the following conclusion.

But Nobel winners from outside the Western tradition have rarely been commended for their universal artistic qualities. It is instead their links to national cultural roots that have been praised, implying that non-Western literatures are insufficiently advanced to be prized for their intrinsic artistic qualities and are valuable mainly as sociopolitical documents, as national obsessions.

This tendency is reflected in the paratexts of Spanish translations. On the dust covers of La montaña del alma and El libro de un hombre solo, Gao Xingjian is described as a "political refugee in Paris." Book reviews also stress the political dimension of his writing.

But the Nobel Prize awarded to Gao today also praises the political dimension of his works. The essence of this political dimension is found in his second novel, One Man's Bible, "his retribution for the terrifying madness known as the Cultural Revolution." (Europa Press 2000)22

The tanks could not do anything against him. (Arrabal 2000) ${ }^{23}$

The Swedish Academy grants the dissident Gao Xingjian a Nobel Prize with a clear political intention. The first Chinese who won this award had to go into exile not long before the Tieanmen [sic.] massacre. (Villar Mir 2000) ${ }^{24}$

Gao Xingjian has been awarded the Nobel Prize, a symbol of Chinese political dissidence. (Frade 2000) ${ }^{25}$

His works are forbidden: the authorities would have preferred an obedient author. (Fernández Arce 2000) ${ }^{26}$

Gao Xingjian's reception is especially incongruous given his promotion of "cold literature" (lengde wenxue 冷的文学), a form of apolitical literature with solely artistic and aesthetic value. An essential contradiction exists between the author's beliefs and the international reception of his works (Prado-Fonts 2008).

The Cultural Revolution and trauma are also recurring themes in paratexts and book reviews. They appear most frequently in accounts of novels written in English and French by ethnic Chinese authors. It is important to note that in the Spanish 
reception, all literature written by authors of Chinese origin, whether in Chinese or in other languages, such as English and French, is labelled as "Chinese literature" in book reviews, press articles and even book covers, without attention to the context of production, the language or the target readership.

Jung Chang's Wild Swans illustrates this recurring motif. This "memoir of victimhood," as described by Chen (2008), enhances the West's fascination with the Orient, offering an unbalanced account of China's traumatic past (the Cultural Revolution). It ends happily when the main character reaches the West and starts a new life. Chen (2008) showed that this type of memoir contributes to a new discourse of self-orientalisation. The clear-cut division between good and evil characters reinforces the simplification of the complex Chinese reality and stresses the idea of a remote and exotic Orient.

The Spanish translation of Wild Swans, entitled Cisnes salvajes, has been published by two publishers and reprinted 18 times. The success of such memoirs on the Cultural Revolution is partly due to their inclusion of the various elements mentioned in this article: they are presented as real and insist on their authenticity; they emphasise difference and exoticism; and they are often censored.

\section{Conclusion}

The purpose of this article has been to demonstrate the marginalised position of modern and contemporary Chinese literature in Spain and the influence of Anglophone and Francophone literary systems on the Spanish reception of this literature. The article has focused on a quantitative analysis of 84 works followed by a qualitative analysis of their paratexts. It has contributed to the theoretical literature on indirect translation by adding complexity to this phenomenon in various ways. The examination of the historical evolution of direct and indirect translations has proven Toury's 1995 premise incorrect by revealing that more cultural contact does not lead to more direct translations. The empirical evidence has shown that the literary market determines literary flows by following a logic based on economic premises. This study has also contradicted Toury's assumption that translations are "facts of the culture which hosts them" (Toury 1995: 24) - the constraints governing these translations operate both in the mediating cultures and in the target culture. In other words, English and French translations of Chinese literature are facts of Spanish culture, too. This study has also demonstrated that indirectness goes beyond translations based on another translation since even direct translations have been mediated by English and French renditions. Most of the novels translated directly from Chinese into Spanish between 2001 and 2010 were chosen by publishers after encountering the French or English translations through literary agents, at literary book fairs or through English and French publishers. This shows that indirectness should be understood as a broad concept that has the potential to stress hidden dynamics in the process of translation. Translation scholars have until recently overlooked indirect translations by including them as part of direct translations (without considering the fact that there is a mediating translation) or excluding them from the history of translations because they are indirect (Marin-Lacarta 2017). In this context, this article has demonstrated the importance of paying attention to indirectness as a way of revealing the hierarchies between literatures and cultures. 
The qualitative analysis of paratexts has complemented Heilbron and Sapiro's (2007: 95-96) categorisation of central and peripheral languages. According to these two authors, Spanish and Chinese are considered semi-peripheral and peripheral languages, while English occupies a hyper-central position (50\% of all translations are from English) and French a central position (accounting for between 10\% and $12 \%$ of all translations). Therefore, the reception of a peripheral literature in a semiperipheral context is influenced by its reception in central languages. Heilbron and Sapiro's classification is based on numbers of translations issued from one language to another and their percentage in relation to the total world market of translated literature. However, this article has shown that this hierarchy is not merely quantitative and has to do with a complex set of attitudes and dynamics that govern the political economy of the global circulation of literature. In this sense, this article has meticulously revealed the features that reflect the incomplete assessment of a semiperipheral literature. In sum, this article has contributed to de-centralize theoretical reflections on the circulation of literature and has shown the multiplicity and complexity of power relations between various literary systems.

\section{NOTES}

1. Chinese names and titles are given in pinyin followed by Chinese characters on first appearance.

2. The first Basque translation appeared in 2013: Mo, Yan (2013): Hori da umorea, maisu! (Translated from Chinese by Maialen Marin-Lacarta and Aiora JAKa Irizar) Donostia: Elkar.

3. Although other authors (such as Pellat 2013) have treated book reviews as paratexts, I follow Genette (1987) in restricting the definition of paratexts to elements written or produced by the author or one of his associates, such as the editor.

4. The first date is the publication date of the Chinese original and the second date is the publication date of the Spanish translation, both for direct and indirect translations. All of the excerpt translations and emphases are mine. TIE, Ning (1983/1989): La blusa roja sin botones. (Translated from Chinese by Taciana FisAC) Madrid: SM [reissued in 1990].

5. Lu, Wenfu (1983/1994): El gourmet: vida y pasión de un gastrónomo chino. (Translated from French by Pilar Giralt Gorina) Barcelona: Seix Barral.

6. LeE, Lilian (also Li, Bihua) (1990/1995): La última princesa de Manchuria. (Translated from English by Victor Pozanco) Barcelona: Ediciones B [reissued in 1996].

7. Zhang, Jie (1982/1995): Galera. (Translated from Chinese by Isabel Alonso) Tafalla: Txalaparta.

8. WANG, Anyi (1985/1996): Baotown. (Translated from English by Herminia DaUer) Barcelona: Juventud.

9. Hong, Ying (1992/1998): El verano de la traición. (Translated from Chinese by Lola Díez PAstor) Barcelona: Plaza \& Janes.

10. Hong, Ying (1997/2005): Hija del río. (Translated from English by Ana Herrera Ferrer) Barcelona: El Aleph.

11. Mo, Yan (1988/2008): Las baladas del ajo. (Translated from English by Carlos Ossés) Madrid: Kailas.

12. Seabra, Manuel de (1975): Prólogo. In: Zedong Mao. Poemas. (Translated from Portuguese by Joaquín HorTa) Barcelona: Aymà, 5-22.

13. Lu, Xun (1923/1971): Obras I: Grito de llamada. (Translated from Chinese by Iñaki Preciado and Miguel Shino) Madrid: Alfaguara.

14. Soler-Pont, Anna (21 May 2008): Una literatura inmensa y desconocida: aproximación a una literatura de raíces milenarias. El Periódico de Catalunya.

15. Lafuente, Fernando R. (26 August 1994): El rastro perdido. ABC, 12.

16. Hong, Ying (1992/1998): El verano de la traición. (Translated from Chinese by Lola DíEz Pastor) Barcelona: Plaza \& Janes.

17. Weinui (also Zhou, Weihui) (1999/2002): Shanghai Baby. (Translated from Chinese by Romer Alejandro Cornejo and Liljana Arsovska) Barcelona/Buenos Aires: Planeta/Círculo de Lectores/ Emecé [reissued by Planeta in 2003, 2004, 2005]. 
18. Chun, Sue (also Chun, Shu) (2002/2003): La nina de Pequín. (Translated from Chinese by Sara Rovira) Barcelona: Empúries.

19. YAN, Lianke (2005/2008): Servir al pueblo. (Translated from French by Ana Herrera Ferrer) Madrid: Maeva.

20. See, for example, Anonymous (31 July 2008): Panorama de la novela actual: China 2008. El Cultural; Arrabal, Francisco (13 October 2000): Los tanques no pudieron con él. ABC, 48; РосH, Rafael (15 October 2009): La literatura contemporánea china, en el torbellino de la modernización. La Vanguardia; Reinoso, José (19 December 2007): Entrevista: Almuerzo con... Chun Shu: "Mi rebeldía es una forma de ser.” El País; Rodríguez, Juan Carlos (26 July 2008): Once novelas chinas y un epílogo olímpico. Ecodiario.es. Consulted on 31 January 2017, <http://ecodiario.eleconomista. es/noticias-ss/noticias/ 670892/07/08/Once-novelas-chinas-y-un-epilogo-olimpico.html>.

21. Hong Ying's blog can be found at http://blog.sina.com.cn/hongyinghongying.

22. Europa Press (12 October 2000): Crónica-Nobel Literatura. Europa Press - Servicio internacional.

23. Arrabal, Francisco (13 October 2000): Los tanques no pudieron con él. ABC, 48.

24. Villar Mir, Carmen (13 October 2000): La Academia Sueca otorga al disidente Gao Xingjian un Nobel con clara intención política. $A B C$.

25. Frade, Cristina (13 October 2000): El Nobel premia la obra de Gao Xingjian, símbolo de la disidencia política china. El Mundo.

26. Fernández Arce, Antonio (13 October 2000): Agria reacción de Pekín, similar a la del Nobel de Paz del Dalai Lama. $A B C, 48$.

\section{REFERENCES}

Ahmad, Aijaz (1992): Jameson's Rhetoric of Otherness and the 'National Allegory.' In: Aijaz Ahmad. Theory: Classes, Nations, Literatures. London/New York: Verso, 92-122.

Arbillaga, Idoia (2003): La literatura china traducida en España. San Vicente del Raspeig: Publicaciones de la Universidad de Alicante.

Assis Rosa, Alexandra, Pięta, Hanna and Bueno Maia, Rita, eds. (2017): Indirect Translation: Theoretical, Methodological and Terminological Issues. Translation Studies. 10(2).

Bergère, Marie-Claire (1995): Introduction: l'enseignement du chinois à l'École des Langues Orientales du XIX ${ }^{e}$ au XXI ${ }^{e}$ siècle. In: Marie-Claire Bergère and Angel Pino, eds. Un siècle d'enseignement du chinois à l'École des langues orientales 1840-1945. Paris: L'Asiathèque, 13-28.

Braester, Yomi (2003): Witness Against History: Literature, Film and Public Discourse in Twentieth-century China. Stanford: Stanford University Press.

Chen, Letty Lingchei (2008): Translating Memory, Transforming Identity: Chinese Expatriates and Memoirs of the Cultural Revolution. Tamkang Review. 38(2):25-40.

Chow, Rey (1993): The Politics and Pedagogy of Asian Literatures in American Universities. In: Rey Chow. Writing Diaspora: Tactics of Intervention in Contemporary Cultural Studies. Bloomington: Indiana University Press, 120-143.

Cronin, Michael (2009): Minority. In: Mona Baker and Gabriela Saldanha, eds. Routledge Encyclopedia of Translation Studies. London: Routledge, 169-172.

Détrie, Muriel and Moura, Jean-Marc (2001): Introduction. Revue de littérature comparée. 297(1):5-11.

Dirlik, Arif (2010): Asia Pacific Studies in an Age of Global Modernity. In: Terence WesleySмith and Jon Goss, eds. Remaking Area Studies: Teaching and Learning Across Asia and the Pacific. Honolulu: University of Hawaii Press, 5-23.

Dolezelova-Velingerova, Milena (1977): The Origins of Modern Chinese Literature. In: Merle Goldman, ed. Modern Chinese Literature in the May Fourth Era. Cambridge: Harvard University Press, 17-35.

Eco, Umberto (1980/1983): The Name of the Rose. (Translated by William Weaver) New York: Harcourt.

Genette, Gérard (1987): Seuils. Paris: Seuil.

Heilbron, Johan and SAPIro, Gisèle (2007): Outlines for a sociology of translation: current issues and future prospects. In: Michaela Wolf, ed. Constructing a Sociology of Translation. Amsterdam/Philadelphia: John Benjamins Press, 93-107. 
Jaka Irizar, Aiora and Marin-Lacarta, Maialen (2014): Txinatar literatura euskaraz: zeharbidezko itzulpenetatik zuzenekoetara itzultzaile-bikoteen eskutik [Chinese Literature in Basque: towards Direct Translations through Teamwork]. Uztaro. 89:39-64.

Jameson, Frederic (1986): Third World Literature in the Era of Multinational Capitalism. Social Text. 15:65-88.

LeE, Leo Ou-fan (1989): Literary Trends I: The Quest for Modernity, 1895-1927. In: John King Fairbank and Yi-tsi Mei Feuerwerker, eds. The Cambridge History of China. Vol. 12. Cambridge: Cambridge University Press, 452-504.

Lovell, Julia (2006): The Politics of Cultural Capital: China's Quest for a Nobel Prize in Literature. Honolulu: University of Hawaii Press.

Marin-Lacarta, Maialen (2012): A Brief History of Translations of Modern and Contemporary Chinese Literature in Spain (1949-2009). 1611 A Journal of Translation History. 6. Consulted on 24 January 2017, <http://www.traduccionliteraria.org/1611/art/marin2.htm>.

Marin-LaCARTA, Maialen (2014): Reclamos reiterativos en las traducciones de literatura china moderna y contemporánea en España. In: Gabriel García-Noblejas Sánchez-Cendal ed. Estudios de traducción e interpretación chino-español. Granada: Editorial Universidad de Granada, 57-101.

Marin-Lacarta, Maialen (2017): Indirectness in Translation: Methodological Possibilities. In: Alexandra Assis Rosa, Hanna Pięta and Rita Bueno Maia, eds. Indirect Translation: Theoretical, Methodological and Terminological Issues. Translation Studies. 10(2).

Miyoshi, Masao and Harootunian, Harry D. (2002): The 'Afterlife' of Area Studies. In: Masao Miyoshi and Harry D. Harootunian, eds. Learning Places: The Afterlives of Area Studies. Durham: Duke University Press, 1-18.

Ollé, Manel (2007): Àsia Oriental en les lletres catalanes del segle XX: versions, ficcions i afeccions. In: Josep Maria Delgado, Jordi Ibáñez, Josep Pich Mitjana, et al., eds. Antoni Saumell i Soler. Miscel-lània in memoriam. Barcelona: Universitat Pompeu Fabra, 617-640.

Pellat, Valerie, ed. (2013): Text, Extratext, Metatext and Paratext in Translation. Cambridge: Cambridge Scholars.

PIÆ̨TA, Hanna (2016): On translation between (semi-)peripheral languages: an overview of the external history of Polish literature translated into European Portuguese. The Translator. 22(3):354-377.

Prado-FonTs, Carles (2001): Del xinès al català, traduccions per generació espontània. Quaderns. Revista de traducció. 6:107-117.

Prado-Fonts, Carles (2008): Contra la literatura assetjada: ficcions, obsessions i globalitzacions de la literatura xinesa. Digithum. 10. Consulted on 24 January 2017, <http://www.uoc.edu/ digithum/10/dt/cat/prado.pdf $>$.

SAID, Edward (1978): Orientalism. New York: Viking.

SHIH, Shu-mei (2004): Global Literature and the Technologies of Recognition. PMLA. 119(1):1630.

Toury, Gideon (1995): Descriptive Translation Studies and Beyond. Amsterdam/Philadelphia: John Benjamins.

WANG, David Der-wei (1997): Fin-de-siècle splendor: repressed modernities of late Qing fiction, 1849-1911. Stanford: Stanford University Press.

Xu, Jianzhong (2003): Retranslation: Necessary or Unnecessary. Babel. 49(3):193-202. 